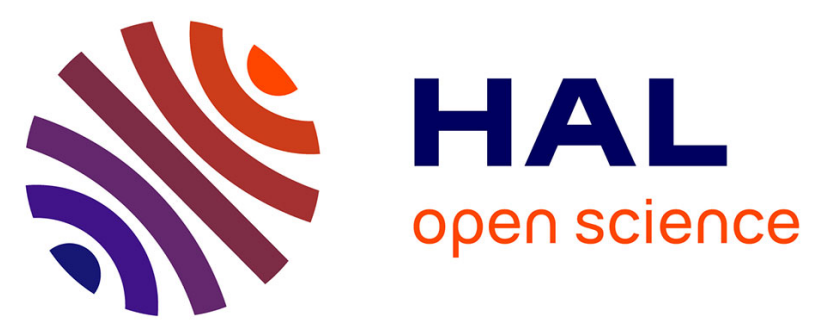

\title{
Population structure and temporal maintenance of the multihost fungal pathogen Botrytis cinerea: causes and implications for disease management.
}

Anne Sophie A. S. Walker, Pierre Gladieux, Véronique Decognet, Marc Fermaud, Johann J. Confais, Jean Roudet, Marc Bardin, Alexandre Bout, Philippe C. Nicot, Christine Poncet, et al.

\section{To cite this version:}

Anne Sophie A. S. Walker, Pierre Gladieux, Véronique Decognet, Marc Fermaud, Johann J. Confais, et al.. Population structure and temporal maintenance of the multihost fungal pathogen Botrytis cinerea: causes and implications for disease management.. Environmental Microbiology, 2015, 17 (4), pp.1261-1274. 10.1111/1462-2920.12563 . hal-02638009

\section{HAL Id: hal-02638009 \\ https://hal.inrae.fr/hal-02638009}

Submitted on 28 May 2020

HAL is a multi-disciplinary open access archive for the deposit and dissemination of scientific research documents, whether they are published or not. The documents may come from teaching and research institutions in France or abroad, or from public or private research centers.
L'archive ouverte pluridisciplinaire HAL, est destinée au dépôt et à la diffusion de documents scientifiques de niveau recherche, publiés ou non, émanant des établissements d'enseignement et de recherche français ou étrangers, des laboratoires publics ou privés.

\section{(ㅇ)(1) $\$$}

Distributed under a Creative Commons Attribution - NonCommerciall 4.0 International 
Version définitive du manuscrit publié dans / Final version of the manuscript : Walker, A. S., Gladieux, P., Decognet, V., Fermaud, M., Confais, J., Roudet, J., Bardin, M., Bout, A., Nicot, P. C., Poncet, C., Fournier, E. (2015). Population structure and temporal maintenance of the multihost fungal pathogen Botrytis cinerea: causes and implications for disease management. Environmental Microbiology, 17 (4), 1261-1274, DOI: 10.1111/1462-2920.12563. The original publication is available at http://onlinelibrary.wiley.com/doi/10.1111/14622920.12563/abstract

\title{
Population structure and temporal maintenance of the multihost fungal pathogen Botrytis cinerea: causes and implications for disease management
}

\author{
Walker Anne-Sophie ${ }^{1 *}$, Gladieux Pierre ${ }^{2,3}$, Decognet Véronique ${ }^{4}$, Fermaud Marc ${ }^{5}$, Confais \\ Johann $^{1}$, Roudet Jean ${ }^{5}$, Bardin Marc ${ }^{4}$, Bout Alexandre ${ }^{6}$, Nicot Philippe ${ }^{4}$, Poncet Christine ${ }^{6}$ and \\ Fournier Elisabeth ${ }^{7}$. \\ ${ }^{1}$ INRA, UR 1290 BIOGER-CPP, Avenue Lucien Brétignières, F-78850 Thiverval-Grignon, France \\ ${ }^{2}$ Univ. Paris Sud, UMR 8079 Ecologie Systématique Evolution, Bâtiment 360, F-91405 Orsay, France; \\ CNRS, F-91405 Orsay, France \\ ${ }^{3}$ Department of Plant and Microbial Biology, University of California, Berkeley, CA 94720, USA \\ ${ }^{4}$ INRA, UR 407 Plant Pathology Unit, Domaine Saint Maurice, F-84140 Montfavet, France \\ ${ }^{5}$ INRA, UMR 1065 SAVE, ISVV, 71 avenue Edouard Bourlaux, F-33882 Villenave d'Ornon, France \\ ${ }^{6}$ INRA, UMR 1355 TEAPEA, F-06903 Sophia-Antipolis, France \\ ${ }^{7}$ INRA, UMR BGPI, TA A 54/K, Campus international de Baillarguet, F-34398 Montpellier, France \\ *walker@versailles.inra.fr
}

\begin{abstract}
Understanding the causes of population subdivision is of fundamental importance, as studying barriers to gene flow between populations may reveal key aspects of the process of adaptive divergence and, for pathogens, may help forecasting disease emergence and implementing sound management strategies. Here, we investigated population subdivision in the multi-host fungus Botrytis cinerea, based on comprehensive multiyear sampling on different hosts in three French regions. Analyses revealed a weak association between population structure and geography, but a clear differentiation according to the host plant of origin. This was consistent with adaptation to hosts, but the distribution of inferred genetic clusters and the frequency of admixed individuals indicated a lack of strict host-specificity. Differentiation between individuals collected in the greenhouse (on Solanum) and outdoor (on Vitis and Rubus) was stronger than that observed between individuals from the two outdoor hosts, probably reflecting an additional isolating effect associated with the cropping system. Three genetic clusters coexisted on Vitis, but did not persist over time. Linkage disequilibrium analysis indicated that outdoor populations were regularly recombining, whereas clonality was predominant in the greenhouse. Our findings open up new perspectives for disease control by managing plant debris in outdoor conditions, and reinforcing prophylactic measures indoor.
\end{abstract}

Keywords: population structure, reproductive isolation, divergent selection, crop management, reproductive system, migration, host plant, gray mold, Botrytis cinerea 


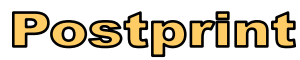

Version définitive du manuscrit publié dans / Final version of the manuscript : Walker, A. S., Gladieux, P., Decognet, V., Fermaud, M., Confais, J., Roudet, J., Bardin, M., Bout, A., Nicot, P. C., Poncet, C., Fournier, E. (2015). Population structure and temporal maintenance of the multihost fungal pathogen Botrytis cinerea: causes and implications for disease management. Environmental Microbiology, 17 (4), 1261-1274, DOI: 10.1111/1462-2920.12563. The original publication is available at http://onlinelibrary.wiley.com/doi/10.1111/14622920.12563/abstract

\section{INTRODUCTION}

Most eukaryotic microbial pathogens are subdivided into distinct populations (Taylor et al., 2006). Understanding the causes of population subdivision is of fundamental importance to population biologists, as studying barriers to gene flow in populations that are not yet completely reproductively isolated may reveal key aspects of the process of adaptive divergence before they become confounded by other factors. Knowledge on the processes that shaped population structure should ultimately allow efficient forecasting and preventing the emergence of genotypes, populations or species with negative effects on ecosystem health and human welfare (McDonald and Linde, 2002; Giraud et al., 2010; Williams, 2010; Gladieux et al., 2011b). An accurate description of the population structure of pathogens is also needed to answer questions about the existence of pathogen reservoirs and the transmissibility or longevity of populations (Milgroom and Peever, 2003; Taylor and Fisher, 2003; Gladieux et al., 2011b; Simwami et al., 2011).

Population differentiation may be adaptive or non adaptive, and may be caused by limited dispersal, limited mating preferences and/or limited adaptation, the consequence being the divergence of gene frequencies between demes. Host-specific or geographic differentiation has been extensively investigated in fungal plant pathogens, and subdivision into multiple populations associated with different hosts or regions has been demonstrated for many species (Peever et al., 2000; Giraud et al., 2006; Gladieux et al., 2008; Gladieux et al., 2011a; Dutech et al., 2012; Robert et al., 2012). The role of other structuring factors, such as i) ecosystem features, e.g. wild vs. agricultural ecosystems (Munkacsi et al., 2008; Stukenbrock and McDonald, 2008; Gladieux et al., 2010); ii) abiotic factors, e.g. temperature (Frenkel et al., 2010; Zhan and McDonald, 2011; Mboup et al., 2012); iii) agrosystem subunits or cropping systems, e.g. nursery $v s$ commercial fields (Peever et al., 2000), has been much less thoroughly investigated. Temporal changes in population structure have also seldom been investigated (Ali et al., 2013). Multiyear sampling can provide access to key features of pathogen population dynamics, such as variation in migration intensity over time and space, the existence of barriers to gene flow, or the prevalence of disease spillover (i.e. cross-species disease transmission) and hybridization (Gladieux et al., 2011b).

Botrytis cinerea (teleomorph Botryotinia fuckeliana) is a filamentous, heterothallic ascomycete fungus causing gray mold on more than 220 host plants, including high-value crops, such as grapevine and tomato, and wild species, such as bramble (Elad et al., 2004). This fungal pathogen can also develop saprophytically, and it is widespread in the environment (Martinez et al., 2005; Gordon and Leveau, 2010). The pathogen spreads through asexual cycles in spring and summer, mostly dispersed by wind and human activities (Elmer and Michailides, 2004). Although signatures of recombination indicate the existence of sexual reproduction in overwintering field populations (Giraud et al., 1997; Fournier and Giraud, 2008), and although sex can be elicited in the lab, ascocarps are rarely observed in field conditions (Beever and Weeds, 2004). Botrytis cinerea was long thought to be a single, though morphologically variable and generalist species. However, several recent studies have shown $B$. cinerea to be a species complex, the cryptic species Botrytis pseudocinerea (teleomorph Botryotinia pseudofuckeliana) 


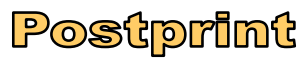

Version définitive du manuscrit publié dans / Final version of the manuscript : Walker, A. S., Gladieux, P., Decognet, V., Fermaud, M., Confais, J., Roudet, J., Bardin, M., Bout, A., Nicot, P. C., Poncet, C., Fournier, E. (2015). Population structure and temporal maintenance of the multihost fungal pathogen Botrytis cinerea: causes and implications for disease management. Environmental Microbiology, 17 (4), 1261-1274, DOI: $10.1111 / 1462-2920.12563$. The original publication is available at http://onlinelibrary.wiley.com/doi/10.1111/14622920.12563/abstract

being found in sympatry with $B$. cinerea, but at low frequency (Albertini et al., 2003; Fournier et al., 2003; Fournier et al., 2005; Martinez et al., 2008; Walker et al., 2011; Johnston et al., 2013). Population genetic surveys using microsatellite and transposable element markers have reported contrasting patterns of host-specific differentiation within $B$. cinerea. No significant genetic differentiation was found between isolates collected from grape, kiwifruit, pea, and squash in the Californian Central Valley (Ma and Michailides, 2005), but other studies revealed significant differentiation between isolates collected from grape, tomato, kiwifruit and bramble in Chile (Munoz et al., 2002), from grape and bramble in France (Fournier and Giraud, 2008), from grape, tomato, faba bean and strawberry in Tunisia (Karchani-Balma et al., 2008) and also between wild hosts in UK (Rajaguru and Shaw, 2010). The existence of host-specific differentiation raises the question of the role of adaptation to the host in the establishment of barriers to gene flow between sympatric $B$. cinerea populations. The components of the life cycle of $B$. cinerea are not fully understood. However, as in many ascomycete pathogens that reproduce on the plant on which their spores initially landed, dispersal between selection on the host and mating may be limited in $B$. cinerea thereby facilitating host-specific differentiation (Giraud et al., 2006; Giraud et al., 2010). In addition to the divergent selection pressures exerted by hosts, other factors may shape the population structure of $B$. cinerea. The role of the saprotrophic phase of $B$. cinerea life cycle is of particular interest as it might serve as a source of inoculum for new epidemics, or lead to the appearance of recombinant genotypes through mating between populations adapted to different habitats. Another major factor that should be considered is geographic distance. Previous studies have shown differentiation between populations of B. cinerea from different continents (South Asia and Australia; Isenegger et al., 2008), but patterns of geographical subdivision seemed to be weaker at smaller scales (Fournier and Giraud, 2008; Karchani-Balma et al., 2008).

Here, considering this context, we hypothesize that $B$. cinerea populations may evolve according to time, space, host and anthropic activities but that evolution patterns still need to be understood in crop production conditions specific to France. Therefore, we investigated the population structure of $B$. cinerea using a comprehensive hierarchical sampling over a two-year period, with four sampling dates, and several host plants, regions and cropping systems in France. We addressed the following questions: (i) Are sampling date, host plant and geographic location structuring genetic variation? (ii) Is the same population structure observed in different regions? (iii) Is population structure stable over time? (iv) What is the role of sexual reproduction in the temporal maintenance of populations?

\section{RESULTS}

We collected 3546 B. cinerea strains over the period of two years, in three regions of France (North-East, South-West, South-East), on litter and on three hosts (Solanum lycopersicum, Vitis vinifera and Rubus fruticosus) under two different management regimes (indoor and outdoor) (Fig. 1; Table 1). All strains were genotyped using eight microsatellite markers (Fournier et al., 2002). 


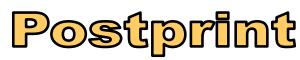

Version définitive du manuscrit publié dans / Final version of the manuscript : Walker, A. S., Gladieux, P., Decognet, V., Fermaud, M., Confais, J., Roudet, J., Bardin, M., Bout, A., Nicot, P. C., Poncet, C., Fournier, E. (2015). Population structure and temporal maintenance of the multihost fungal pathogen Botrytis cinerea: causes and implications for disease management. Environmental Microbiology, 17 (4), 1261-1274, DOI: 10.1111/1462-2920.12563. The original publication is available at http://onlinelibrary.wiley.com/doi/10.1111/14622920.12563/abstract

\section{Population subdivision}

We first examined the partitioning of genetic variation among the different potential factors shaping population subdivision (sampling date, host plant and geographic location; Table 1) using hierarchical analyses of molecular variance (AMOVA) (Table 2). In a first AMOVA in which populations of the full dataset were organized by sampling date, variation among dates was highly significant $\left(P<0.0001 ; F_{S T}=0.32\right)$ even if variation within dates accounted for most of the molecular variance $(67.43 \% ; P<0.0001)$. In a second set of AMOVAs performed separately for each sampling date, we explored the distribution of genetic variation among regions and among hosts of origin (Vitis, Rubus or Solanum) nested within the three regions (Northeast, Southeast and Southwest). Variation within populations accounted for most of the molecular variance $\left(70-77 \% ; P<0.001 ; 0.19<F_{S T}<0.29\right)$. Variation among hosts within regions accounted for 23 to $34 \%$ of molecular variance $(P<0.001)$, whereas variation among regions was never significant. These results suggest that the two main factors significantly affecting the genetic variance in our dataset were sampling date and host of origin, whereas geographic origin played a minor role.

We investigated patterns of population subdivision using the clustering method implemented in STRUCTURE, assuming a model with admixture and correlated allele frequencies. Analyses were performed independently for each sampling date, without using prior information regarding the host or region of origin of genotypes. The rate of change in the log probability of data between successive $K$ values $(\Delta K)$ exhibited a mode at $K=5$ for the June 2006, September 2006 and June 2007 datasets, and at $K=2$ for the September 2005 dataset (Supporting Information Table 1). We then compared the results obtained with STRUCTURE, which is a model-based clustering method assuming linkage and Hardy-Weinberg equilibrium within subpopulations, with those obtained with DAPC, a non-parametric multivariate clustering method. This latter analysis revealed essentially the same pattern as STRUCTURE analyses, with five distinct groups inferred whatever the sampling date considered (Supporting Information Fig. 1). In subsequent analyses, we used the clustering patterns inferred with STRUCTURE for $K=5$ at all sampling dates (Fig. 2 lines A, B, D, F).

Whatever the sampling date considered, one cluster consisted mostly of isolates collected in greenhouses on Solanum (on average per season, $83 \%$ of genotypes from this habitat had membership coefficients of 0.73-0.98 in the same cluster, with a mean of 0.96). Another cluster was mostly composed of isolates collected on Rubus (on average per season, $47 \%$ of genotypes collected on this host had membership coefficient of 0.72-0.98 in the same cluster, with a mean of 0.94). The proportion of isolates collected on Rubus grouping in this cluster was higher in spring (95\% and 89\% in June 2006 and 2007, respectively), than in fall (57\% and 63\% in September 2005 and 2006, respectively). The last three clusters grouped together isolates collected mostly from Vitis, with an average of $69 \%$ of the isolates collected on this host having membership coefficients above 0.70 in one of the three clusters (mean 0.90). No cluster specifically grouped together isolates collected on litter, which were distributed mostly across the three Vitis clusters (4.7\%-25.3\% of the genotypes assigned to these clusters were collected on litter). Litter was thus considered to be essentially the same as Vitis in subsequent analyses. 


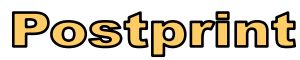

Version définitive du manuscrit publié dans / Final version of the manuscript : Walker, A. S., Gladieux, P., Decognet, V., Fermaud, M., Confais, J., Roudet, J., Bardin, M., Bout, A., Nicot, P. C., Poncet, C., Fournier, E. (2015). Population structure and temporal maintenance of the multihost fungal pathogen Botrytis cinerea: causes and implications for disease management. Environmental Microbiology, 17 (4), 1261-1274, DOI: 10.1111/1462-2920.12563. The original publication is available at http://onlinelibrary.wiley.com/doi/10.1111/1462$2920.12563 /$ abstract

Across sampling dates, pairwise $F_{S T}$ between clusters ranged between 0.12 and 0.65 (mean of 0.40 , all $F_{S T}$ values being significant), and population differentiation was always greater between clusters grouping genotypes from different hosts (range: $0.20-0.65$, mean 0.43 ) than between the clusters coexisting on Vitis (range 0.12-0.30, mean 0.23; Supporting Information Table 2). Hence, consistent with the results of AMOVA, clustering analyses indicated that whatever the sampling date, genetic variation in $B$. cinerea populations was mainly structured according to the host plant, with geographic location having a much weaker effect.

\section{Temporal maintenance of population subdivision}

To investigate the maintenance over time of the pattern of population subdivision in five genetic clusters we first performed a PCA to visualize the relationships among the 20 groups formed by the five genetic clusters inferred at each season (Fig. 3). Only genotypes with membership greater than 0.7 in a given cluster were considered. The four clusters inferred on Solanum (SOLANUM clusters) at the different sampling dates were clearly grouped together. The four clusters inferred on Rubus (RUBUS clusters) were also separated from the others, but formed two groups, one group for spring sampling dates, the other for fall sampling dates. The 12 clusters inferred on Vitis (VITIS clusters) formed a third undifferentiated group.

We also investigated the temporal maintenance of subdivision using the option in STRUCTURE allowing assignment of focal individuals to populations defined a priori as reference populations. Here, we considered all individuals from a given sampling date $(t)$, and inferred their proportion of ancestry in the 5 genetic clusters inferred at the previous sampling date $(t-1)$ (the 5 'reference' populations). To increase the stringency of the analysis, the five genetic clusters of date $t-1$ were defined as reference populations on the basis of genotypes that had membership coefficients greater than 0.9 in any of these clusters. Genotypes from date $t$ were considered 'assigned' to a given cluster from data $t-1$ if their membership coefficient in this cluster was above 0.70 . Across seasons, $66.8 \%$ to $85.9 \%$ of the genotypes sampled on Solanum at date $t$ were assigned to the SOLANUM cluster inferred at date $t-1$ (Fig. 2; Table 3). Only $0.5 \%$ to $11.7 \%$ of genotypes from Solanum were assigned to the VITIS or RUBUS clusters, and the remaining genotypes were admixed and could not be assigned to any cluster. Individuals sampled on Rubus in June 2006 and September 2006 were mostly assigned to the RUBUS clusters from date $t-1$ (40.6\% to $75.6 \%$ of genotypes), while individuals collected in June 2007 were mostly assigned to the VITIS cluster (56.8\% of genotypes), and $15.1 \%$ to $36.7 \%$ of genotypes were admixed and could not be assigned to any cluster (Fig. 2; Table 3). Genotypes sampled on Vitis at a given date $t$ tended to be assigned to the VITIS clusters of date $t-1$ (25.3\% to $48.7 \%$ of genotypes) but a relatively greater proportion of genotypes, compared to other host plants, was not assigned to any of the three clusters identified at date $t-1$ (50.0 to $59.2 \%$ of genotypes) showing that the three VITIS clusters were not stable over time, probably due to regular recombination among individuals infecting this plant (Fig. 2; Table 3). Individuals collected in litter were assigned to the RUBUS clusters ( $0 \%$ to $21.6 \%$ of genotypes), to the VITIS clusters (21.6\% to $63.0 \%$ of genotypes) or not assigned to any cluster (37.0\% to $56.8 \%$ of genotypes), but none was assigned to the SOLANUM clusters. Altogether, these results indicate that the population subdivision of $B$. cinerea is globally maintained throughout time. 


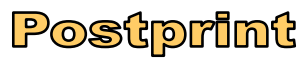

Version définitive du manuscrit publié dans / Final version of the manuscript : Walker, A. S., Gladieux, P., Decognet, V., Fermaud, M., Confais, J., Roudet, J., Bardin, M., Bout, A., Nicot, P. C., Poncet, C., Fournier, E. (2015). Population structure and temporal maintenance of the multihost fungal pathogen Botrytis cinerea: causes and implications for disease management. Environmental Microbiology, 17 (4), 1261-1274, DOI: 10.1111/1462-2920.12563. The original publication is available at http://onlinelibrary.wiley.com/doi/10.1111/14622920.12563/abstract

\section{Patterns of genetic variability}

Having evidenced patterns of population subdivision, we next investigated how genetic variability varied within each subpopulation in order to get insight into population dynamics. We estimated genetic variability within each clusters at each sampling date, by estimating the mean number of alleles per locus, $A_{r}$, and the genic diversity, $H_{e}$ (Fig. 4). The SOLANUM clusters were the least variable, with $A_{r}$ values ranging between 2.63 and 3.88 over time, and $H_{e}$ not exceeding 0.32 . Genetic variability was higher in all other clusters, but with different ranking among them, depending on the sampling date. In the RUBUS cluster, the inter-date standard deviations of $A_{r}$ and $H_{e}$ were 5.19 and 0.21 , respectively ( $A_{r}$ range: $3.75-16.00 ; H_{e}$ range: $0.34-0.81$ ). In the three VITIS clusters, $A_{r}$ ranged from 3.63 to 15.38 and $H_{e}$ ranged from 0.31 to 0.81 . Inter-date standard deviations could not be computed for these latter clusters, as they did not appear to be maintained through time.

\section{Mode of reproduction}

To investigate the reproductive mode within each $B$. cinerea subpopulation we used the proportion of genotypes repeated at multiple times (clonal fraction) and an estimate of multilocus linkage disequilibrium: the $r_{D}$ index (Fig. 5). For each season, we also considered all possible pairs of loci and determined whether these pairs were significantly linked or not, using Fisher's exact tests, and estimated the proportion of pairs for which linkage status changed over time. These data were represented using "transition graphs" from on sampling date to the other (Supporting Information Fig. 2).

The highest clonal fraction was found in the SOLANUM clusters (from 0.75 to 0.91). In these clusters, multilocus linkage disequilibrium, estimated with the $r_{D}$ index, varied from 0.18 to 0.34 over time and was lower in June samples than for those collected at the previous sampling date (September). Transition graphs showed that in the SOLANUM cluster, most pairs of loci $(57$ to $76 \%$ ) remained linked over time (Supporting Information Fig. 2). Together, these results suggest that asexual reproduction is probably the main mode of reproduction in the SOLANUM cluster.

In the RUBUS clusters, $r_{D}$ values were low and varied little between seasons (range 0.070.14), contrasting with the SOLANUM cluster (Fig. 5). The clonal fraction was below 0.50 and peaked at the end of summer (0.14 and 0.16 in September 2005 and September 2006, respectively). Transition graphs (Supporting Information Fig. 2) confirmed that $36 \%$ to $39 \%$ of the statistical associations between pairs of loci were not observed anymore between fall and the following spring. This suggests that regular recombination events occurred within the RUBUS cluster, and that reproduction probably took place during the winter.

In the VITIS clusters, $r_{D}$ values were always lower than in the RUBUS cluster, varying between 0.02 and 0.14 , depending on the collecting date. The clonal fraction ranged between 0.10 and 0.58 , and was always lower in spring (0.11-0.37 for June 2006, 0.10-0.31 for June 2007) than in fall (0.32-0.55 for September 2005, 0.34-0.58 for September 2006). Thus, as for the RUBUS cluster, recombination probably occurred regularly within and among the VITIS clusters, although the time period in which it occurred cannot be inferred due to the lack of any shift in statistical associations between pairs of loci. Since the VITIS clusters do not persist over 


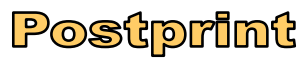

Version définitive du manuscrit publié dans / Final version of the manuscript : Walker, A. S., Gladieux, P., Decognet, V., Fermaud, M., Confais, J., Roudet, J., Bardin, M., Bout, A., Nicot, P. C., Poncet, C., Fournier, E. (2015). Population structure and temporal maintenance of the multihost fungal pathogen Botrytis cinerea: causes and implications for disease management. Environmental Microbiology, 17 (4), 1261-1274, DOI: $10.1111 / 1462-2920.12563$. The original publication is available at http://onlinelibrary.wiley.com/doi/10.1111/14622920.12563/abstract

time (Fig. 2, Table 3), it was not relevant to analyze how linkage disequilibrium between pairs of loci was generated or broken between consecutive dates.

\section{DISCUSSION}

We analyzed associations over seasons between the population structure and the region and host plant of origin of multilocus microsatellite genotypes of the multihost plant pathogen B. cinerea. For all sites and all sampling dates, populations collected from different hosts were significantly differentiated. Genetic variation was also significantly structured according to sampling date. At each date, individuals collected from Rubus and Solanum, respectively, had high membership in distinct clusters (RUBUS and SOLANUM clusters), which persisted over time. Individuals collected on Vitis had a high membership in three different clusters (VITIS clusters) that did not seem to be fully maintained over time, possibly indicating within-host disruptive selective pressures that do not persist through time. Asexual reproduction seemed to be the main reproductive mode in the SOLANUM cluster, which also displayed little admixture with other clusters, whereas footprints of regular recombination and higher levels of admixture were found in the other clusters.

\section{Geography and host plant as factors of isolation}

AMOVA and clustering analyses showed that population structure was only weakly associated with geographic location at the (regional and national) scale used in our study, as already observed at the scale of Britain, French, New-Zealand and Tunisia (Fournier and Giraud, 2008; Karchani-Balma et al., 2008; Rajaguru and Shaw, 2010; Johnston et al., 2013). Previous studies also found that geographic differentiation in chickpea-associated Botrytis populations was only observed at the inter-continental level (Isenegger et al., 2008). The lack of geographic structure suggests extensive migration and/or high population sizes impeding the differentiation of allele frequencies at the scale of our study.

Unlike the geographic origin of samples, the host plant of origin significantly accounted for population subdivision in $B$. cinerea. Host-specific population differentiation has already been described in B. cinerea (Munoz et al., 2002; Fournier and Giraud, 2008; Karchani-Balma et al., 2008; Rajaguru and Shaw, 2010; Samuel et al., 2012), even between hosts as phylogenetically close as strawberry and blackberry (Rajaguru and Shaw, 2010). The divergent selection pressures exerted by hosts may explain the stable pattern of differentiation observed in B. cinerea populations over time. Defense mechanisms specific to different hosts may require distinct sets of pathogenicity alleles/genes involved in necrotrophy (Choquer et al., 2007; Williamson et al., 2007). Genomic sequencing of $B$. cinerea revealed a large number of secondary metabolites such as fungal toxins (Amselem et al., 2011), that might play a role in ecological specialization to different hosts (Giraud et al., 2010). Barriers to gene flow might also be associated with differences in host phenology or periods of receptivity (Desprez-Loustau et al., 2010). 


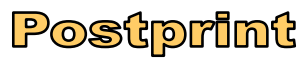

Version définitive du manuscrit publié dans / Final version of the manuscript : Walker, A. S., Gladieux, P., Decognet, V., Fermaud, M., Confais, J., Roudet, J., Bardin, M., Bout, A., Nicot, P. C., Poncet, C., Fournier, E. (2015). Population structure and temporal maintenance of the multihost fungal pathogen Botrytis cinerea: causes and implications for disease management. Environmental Microbiology, 17 (4), 1261-1274, DOI: $10.1111 / 1462-2920.12563$. The original publication is available at http://onlinelibrary.wiley.com/doi/10.1111/14622920.12563/abstract

Different genetic clusters were also observed on the same host, Vitis. This suggests that B. cinerea isolates on Vitis might be partitioned into different ecological niches at very fine scale, which would be interesting to identify in a future study. These clusters might be associated to various host tissues and/or to the degree of physiological maturity of these tissues, as suggested for Zymoseptoria tritici (Brunner et al., 2013). However, we found clear signatures of admixture among these clusters and a lack of persistence through time, suggesting that the putative fine-scale niche partitioning does not prevent gene flow.

Unlike the plant of origin, the nature of the substrate of origin (living plant organs or litter) had no significant effect on the genetic structure of outdoor populations. Litter isolates predominantly clustered with the VITIS populations, consistent with the large surface occupied by vineyards in the three regions under study. The overwintering of grapevine debris was also demonstrated as an important source of B. cinerea inoculum (Elmer and Michailides, 2004; Jaspers et al., 2013). Large amounts of inoculum released from grapevine may furthermore readily colonize dead material present in the immediate neighborhood, which is not systematically sprayed with fungicides and may therefore serve as a reservoir of fungicidesusceptible inoculum. This opens up new possibilities for gray mold management. More drastic prophylactic measures (such as the removal of potential substrates for the pathogen; (Elmer and Michailides, 2004; Boyd-Wilson et al., 2013; Jaspers et al., 2013) could contribute to decrease the amount of resistant inoculum on litter in Vitis crop and to preserve a limited proportion of susceptible inocula kept on outside hosts, able to hinder the evolution of drug resistance.

\section{Strong isolation of populations infecting Solanum}

Several lines of evidence indicated that the SOLANUM cluster was clearly differentiated from other clusters. This relative isolation of populations infecting Solanum may result from a combination of habitat isolation (the greenhouse acts as physical barrier), reduced frequency of sexual reproduction in the greenhouse (decreasing the probability of mating with genotypes adapted to other hosts) and strong natural selection against migrants or hybrids from divergent habitats. These latter ecologically-based barriers to gene flow may be associated with factors such as effective prophylaxis indoors, divergent abiotic conditions between outdoor and indoor environments, or divergent selective pressures exerted by hosts (Solanum belongs to the Asterids subclass, whereas Vitis and Rubus belong to the Rosids subclass (The Angiosperm Phylogeny, 2009)). Additional sampling, comparing locally populations from greenhouse or open-field tomatoes would certainly refine our results.

We also observed differences in diversity between Solanum populations from different regions (Supplementary Information Fig. 3), possibly reflecting differences in the prophylactic measures implemented, the greenhouse structure, climatic conditions or historical factors (number of founding propagules). Nevertheless, clonal fraction in low-tech greenhouses, likely to be exchanging more migrants with outdoor populations, was greater than the one in other outdoor clusters, which confirms that the reproduction mode is mostly asexual in all greenhouses even if some heterogeneity exists among them. The higher relative contribution of asexual reproduction of $B$. cinerea populations in indoor conditions is consistent with previous studies (Karchani-Balma et al., 2008; Decognet et al., 2009). 


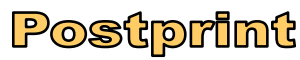

Version définitive du manuscrit publié dans / Final version of the manuscript : Walker, A. S., Gladieux, P., Decognet, V., Fermaud, M., Confais, J., Roudet, J., Bardin, M., Bout, A., Nicot, P. C., Poncet, C., Fournier, E. (2015). Population structure and temporal maintenance of the multihost fungal pathogen Botrytis cinerea: causes and implications for disease management. Environmental Microbiology, 17 (4), 1261-1274, DOI: $10.1111 / 1462-2920.12563$. The original publication is available at http://onlinelibrary.wiley.com/doi/10.1111/14622920.12563/abstract

Altogether, our results suggest that cropping system is an important structuring factor in B. cinerea populations. Prophylactic measures should be implemented to strengthen isolation, such as disinfection between crops and seedlings, quarantine, filtering of the incoming air, weed management in the areas surrounding greenhouses and the use of techniques limiting the introduction of diversity. The confinement of greenhouse populations would ensure that fungicide resistance selected on outdoor crops does not introgress indoor populations. Indeed, analyses of the distribution of resistant genotypes in greenhouse populations have revealed isolates resistant to the limited number of fungicide types used indoors, whereas greater phenotypic diversity is encountered in the surrounding populations collected on grapevine, for which different modes of action are authorized (AS Walker, unpublished data).

\section{Mode of reproduction}

The low clonal fraction and low linkage disequilibrium values are signatures of regular recombination within the RUBUS and VITIS clusters. These findings are consistent with previous studies (Giraud et al., 1997; Fournier and Giraud, 2008), that suggested regular cryptic sexual reproduction in $B$. cinerea populations, despite the fact that sexual structures are hardly observed in natural conditions (Beever and Weeds, 2004).

When possible (i.e., for clusters that persisted over time), the examination of how linkage between pairs of loci changed across time suggested that recombination events in outdoor populations take place during the cold season. In the RUBUS clusters in particular, the proportion of linked pairs was higher at the end of summer than in spring, indicating that linkage disequilibrium is "broken" during winter, probably due to recombination. The period occurrence of recombination could not be inferred with confidence in the three Vitis clusters but previous findings concerning the epidemiology of gray mold suggested that cold conditions are favorable to sexual reproduction of $B$. cinerea (Elmer and Michailides, 2004). Parasexuality due to anastomosis has been hypothesized in B. fuckeliana (Beever and Parkes, 2003; Roca et al., 2012). However, given the observation of the sexual cycle in the lab we favor the hypothesis of a sexual cycle occurring regularly but inconspicuously in nature.

\section{Concluding remarks}

Our comprehensive analysis of $B$. cinerea population structure and dynamics has direct applications for disease management. Understanding the causes of population subdivision, its temporal maintenance, and the flows of genotypes among demes will help to implement management strategies aiming at restricting genetic exchanges between populations. For example, limiting the density of potential host plants in the vicinity of greenhouses or improving litter and wild hosts management in vineyards might significantly decrease the intensity of epidemics but also delay fungicide resistance evolution. The efficiency of these prophylactic measures (detailed in Elmer and Michailides, 2004) are well-known by epidemiologists and agronomists, but our findings underline the genetic mechanisms underlying their success. Such knowledge may be used to better optimize the joint use of the various control methods and hence contribute to increase the sustainability of agricultural production for crops susceptible to $B$. cinerea. 


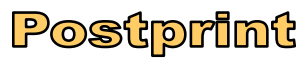

Version définitive du manuscrit publié dans / Final version of the manuscript : Walker, A. S., Gladieux, P., Decognet, V., Fermaud, M., Confais, J., Roudet, J., Bardin, M., Bout, A., Nicot, P. C., Poncet, C., Fournier, E. (2015). Population structure and temporal maintenance of the multihost fungal pathogen Botrytis cinerea: causes and implications for disease management. Environmental Microbiology, 17 (4), 1261-1274, DOI: $10.1111 / 1462-2920.12563$. The original publication is available at http://onlinelibrary.wiley.com/doi/10.1111/14622920.12563/abstract

\section{EXPERIMENTAL PROCEDURES}

\section{Sample collection}

Samples were collected on four dates: September 2005, June 2006, September 2006 and June 2007 (Table 1). June corresponds to the start of the cropping season and the samples collected in this month were presumed to have undergone sexual reproduction during the winter. By contrast, September corresponds to the end of the cropping season, after the occurrence of asexual multiplication on the host. Samples were collected in the Northeast (Champagne), Southwest (Aquitaine) and Southeast (Provence and Côte d'Azur) of France, at two to six separate sites per region (Fig. 1). Sampling sites were separated from 3-180 km within a region and from 340-684 $\mathrm{km}$ between regions. In each region, samples were collected from four different hosts/substrates: (i) tomato (Solanum lycopersicum) in greenhouses, (ii) grapevine (Vitis vinifera), (iii) bramble (Rubus fruticosus), from bushes surrounding vineyards or greenhouses, and (iv) litter in openfield conditions, on various dead wild plants and/or grapevine debris, on the soil within and/or outside the grapevine plots (Table 1). Each local population corresponds to a minimum of 30 samples randomly collected within the plot/greenhouse. Strains were collected on cotton swabs, from sporulating lesions for greenhouse crops, grapevine and bramble in September, and from asymptomatic grapevine flower caps and dried blackberry flowers in June. For June and for litter samples, the fungus was collected following the incubation of the plant material in a moist chamber at room temperature until conspicuous sporulation was observed.

Strains were grown on malt-yeast-agar (MYA) medium (20 g. $\mathrm{l}^{-1}$ malt extract, 5 g. $\mathrm{l}^{-1}$ yeast extract and 12.5 g. $1^{-1}$ agar) or potato dextrose agar (PDA; 39 g. $1^{-1}$ ready-to-mix DIFCO potato dextrose agar), at $19^{\circ} \mathrm{C}$ to $21^{\circ} \mathrm{C}$, under continuous illumination, to induce sporulation. Singlespore cultures, referred to hereafter as "isolates", were obtained for all strains. Stocks of spore suspensions for each isolate were stored in $20 \%$ glycerol, at $-80^{\circ} \mathrm{C}$, until required.

\section{Microsatellite genotyping}

For each isolate, DNA was extracted after seven days of culture on MYA or PDA medium at $21^{\circ} \mathrm{C}$. DNA was extracted in an automated system, with the DNeasy adapted kit (Qiagen), or manually (Martinez et al., 2008; Decognet et al., 2009). All samples were genotyped for eight microsatellite markers - Bc1, Bc2, Bc3, Bc4, Bc5, Bc6, Bc7 and $\mathrm{Bc} 10$ (Fournier et al., 2002) - either in multiplex PCR, as previously described (Leroux et al., 2010), or in simplex PCR. Automatic allele recognition and annotation (binning analysis, Beckmann Coulter CEQ 8000 software) was carried out for the microsatellites for the multiplex analyses, after manual parametrization following the observation of a large number of samples covering as much diversity as possible for each locus. In addition, as genotyping was carried out in several laboratories, a panel of 21 reference isolates was distributed to all the laboratories and used to cross-validate allele assignment. We excluded isolates of the cryptic species $B$. pseudocinerea, which is morphologically undistinguishable from $B$. cinerea, on the basis of a previously described diagnostic allele at locus Bc6 (Walker et al., 2011). Only isolates genotyped at all microsatellite markers were included in the analyses. 


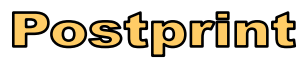

Version définitive du manuscrit publié dans / Final version of the manuscript : Walker, A. S., Gladieux, P., Decognet, V., Fermaud, M., Confais, J., Roudet, J., Bardin, M., Bout, A., Nicot, P. C., Poncet, C., Fournier, E. (2015). Population structure and temporal maintenance of the multihost fungal pathogen Botrytis cinerea: causes and implications for disease management. Environmental Microbiology, 17 (4), 1261-1274, DOI: 10.1111/1462-2920.12563. The original publication is available at http://onlinelibrary.wiley.com/doi/10.1111/14622920.12563/abstract

\section{Analyses of population subdivision}

We used hierarchical analyses of molecular variance (AMOVA) implemented in ARLEQUIN V3.5 (Excoffier and Lischer, 2010) to investigate the relative contributions of sampling date, region of origin and host plant species within regions to the partitioning of genetic variance.

Population subdivision was investigated by the Bayesian clustering method implemented in STRUCTURE (Pritchard et al., 2000). This model-based algorithm assumes linkage equilibrium within inferred genetic clusters, therefore is in principle appropriate for species experiencing regular recombination. However, STRUCTURE has been shown quite robust to departure from panmixia (Morgan et al., 2007; Dutech et al., 2010; Ali et al., 2014); moreover, as outlined earlier, linkage equilibrium within $B$. cinerea populations was observed in several previous studies. Therefore we assume that this method is appropriate to infer $B$. cinera population subdivision. We ran STRUCTURE with the admixture model and correlated allele frequencies. Burn-in length was set at 100,000 Markov Chain Monte Carlo iterations. The burn-in period was followed by a run phase of 500,000 iterations, with the number of clusters $K$ ranging from 1 to 10 and 10 independent replicates for each value of $K$. STRUCTURE outputs were processed with CLumPP (Jakobsson and Rosenberg, 2007); a $G^{\prime}$ statistic greater than $80 \%$ was used to assign groups of runs to a common mode (i.e. clustering solution). The amount of additional information explained by increasing $K$ was determined by calculating the $\Delta K$ statistic (Evanno et al., 2005).

To confirm the pattern of population subdivision inferred using STRUCTURE, we used an alternative, non model-based, clustering method: the discriminant analysis of principal components (DAPC, (Jombart et al., 2010)). This multivariate method involves a discriminant analysis on genetic data transformed after principal component analysis. The DAPC was carried out with the adegenet 1.3-1 package in the $\mathrm{R} 2.13 .1$ environment. We used the K-means procedure implemented in the function find.clusters to determine $K$, the optimal number of clusters, by letting $K$ vary between 1 and 30. We used the Bayesian information criterion (BIC) to determine the 'optimal' value of $K$, defined as the value for which BIC was minimal, or at which the rate of change of BIC changed abruptly.

The temporal maintenance of population subdivision was assessed using assignment tests implemented in STRUCTURE (USEPOPINFO option). Genotypes sampled at season $t$ were assigned into the genetic clusters inferred with STRUCTURE at season $t$ - 1 . Only genotypes having a membership coefficient over or equal to 0.9 in a single cluster at season $t-1$ were used as learning samples. Genotypes of season $t$ were not included in updates of allele frequency estimates (option UPDATEPFROMPOPFLAGONLY). The population model and run length were the same as in clustering analyses. Five independent runs were performed to check for convergence of the algorithm. We also investigated the temporal maintenance of genetic clusters inferred at several season using a PCA on multilocus genotypes categorized by season and genetic clusters within seasons, as implemented in the ADEGENET package of R (Jombart, 2008).

\section{Genetic variability, differentiation among clusters, and mode of reproduction}

Calculations were performed on the clusters inferred using STRUCTURE, considering genotypes having a membership coefficient over 0.7 in a single cluster. GENETIX (Belkhir et al., 1996-2004) was used to estimate within-cluster genetic variability on the basis of genic diversity calculated 


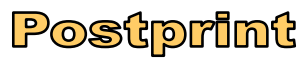

Version définitive du manuscrit publié dans / Final version of the manuscript : Walker, A. S., Gladieux, P., Decognet, V., Fermaud, M., Confais, J., Roudet, J., Bardin, M., Bout, A., Nicot, P. C., Poncet, C., Fournier, E. (2015). Population structure and temporal maintenance of the multihost fungal pathogen Botrytis cinerea: causes and implications for disease management. Environmental Microbiology, 17 (4), 1261-1274, DOI: $10.1111 / 1462-2920.12563$. The original publication is available at http://onlinelibrary.wiley.com/doi/10.1111/14622920.12563/abstract

as multilocus observed heterozygosity $(\mathrm{He})$, and allele richness $(\mathrm{Ar})$. GENEPOP V4.1 (Raymond and Rousset, 1995) was used to calculate pairwise Weir \& Cockerham's $F_{S T}$ between pairs of clusters (Weir \& Cockerham 1984).

The number of unique multilocus genotypes $(\mathrm{G})$ and the clonal fraction $(1-\mathrm{G} / \mathrm{N})$ were calculated with Multilocus V1.3b (Agapow and Burt, 2001). We also used this software to calculate the $r_{D}$ index, an estimate of multilocus linkage disequilibrium. Unlike the $I_{A}$ index, $r_{D}$ is corrected for the number of loci considered, and ranges from 0 (complete panmixia) to 1 (strict clonality). Significance was established by comparing the observed values with the distributions obtained by 1000 randomizations (Agapow and Burt, 2001). We evaluated the significance of pairwise linkage disequilibrium by contingency tests (with default parameters) implemented in GENEPOP V4.1 (Raymond and Rousset, 1995).

\section{ACKNOWLEDGMENTS}

This work was funded by a grant from the INRA "Santé des Plantes et Environnement" Department. Pierre Gladieux was supported by a Marie Curie grant (FP7-PEOPLE-2010-IOFNo.273086). We thank Tatiana Giraud for helpful discussions about the manuscript and Laurence Bill, Isabella Ilisescu, Nouria Taourit, Valérie Mayet Cook, and Cécile Thomas for valuable technical assistance. We thank Michel Gredt, Annick Arnold, Monique Sellier, Pascal Le Pêcheur, Philippe Robin, Angélique Gautier, Michèle Leplat, Claire Troulet for their participation in sample collection in the field. The authors declare that they have no conflict of interest for this work.

\section{REFERENCES}

Agapow, P.M., and Burt, A. (2001) Indices of multilocus linkage disequilibrium. Molecular Ecology Notes 1: 101-102.

Albertini, C., Gredt, M., and Leroux, P. (2003) Polymorphism of 14 alpha-demethylase gene (CYP51) in the cereal eyespot fungi Tapesia acuformis and Tapesia yallundae. European Journal of Plant Pathology 109: 117-128.

Ali, S., Gladieux, P., Leconte, M., Gautier, A., Justesen, A.F., Hovmøller, M.S. et al. (2014) Origin, migration routes and worldwide population genetic structure of the wheat yellow rust pathogen Puccinia striiformis f.sp. tritici. PLoS Pathog 10: e1003903.

Ali, S., Gladieux, P., Rahman, H., Saqib, M.S., Fiaz, M., Ahmad, H. et al. (2013) Inferring the contribution of sexual reproduction, migration and off-season survival to the temporal maintenance of microbial populations: a case study on the wheat fungal pathogen Puccinia striiformis f.sp. tritici. Molecular Ecology: 23(23): 603-617.

Amselem, J., Cuomo, C.A., van Kan, J.A.L., Viaud, M., Benito, E.P., Couloux, A. et al. (2011) Genomic analysis of the necrotrophic fungal pathogens Sclerotinia sclerotiorum and Botrytis cinerea. Plos Genetics 7. 


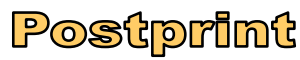

Version définitive du manuscrit publié dans / Final version of the manuscript : Walker, A. S., Gladieux, P., Decognet, V., Fermaud, M., Confais, J., Roudet, J., Bardin, M., Bout, A., Nicot, P. C., Poncet, C., Fournier, E. (2015). Population structure and temporal maintenance of the multihost fungal pathogen Botrytis cinerea: causes and implications for disease management. Environmental Microbiology, 17 (4), 1261-1274, DOI: 10.1111/1462-2920.12563. The original publication is available at http://onlinelibrary.wiley.com/doi/10.1111/14622920.12563/abstract

Beever, R., and Weeds, P. (2004) Taxonomic and genetic variation of Botrytis and Botryotinia. In Botrytis: Biology, pathology and control. Elad, Y., Williamson, B., Tudzynski, P., and Delen, N. (eds). Dordrecht, The Netherlands: Kluwer Academic Publisher, pp. 29-52.

Beever, R.E., and Parkes, S.L. (2003) Use of nitrate non-utilising (Nit) mutants to determine vegetative compatibility in Botryotinia fuckeliana (Botrytis cinerea). European Journal of Plant Pathology 109: 607-613.

Belkhir, K., Borsa, P., Chikhi, L., Raufaste, N., and Bonhomme, F. (1996-2004) Genetix 4.05, logiciel sous Windows TM pour la génétique des populations. Laboratoire Génome, Populations, Interactions, CNRS UMR 5171, Université de Montpellier, Montpellier, France. . http://wwwgenetixuniv-montp2fr/genetix/introhtm.

Boyd-Wilson, K., Obanor, F., Butler, R.C., Harris-Virgin, P., Langford, G.I., Smith, J.T., and Walter, M. (2013) Sources of Botrytis cinerea inoculum for flower infection in blackcurrants in New Zealand. Australasian Plant Pathology 42: 27-32.

Brunner, P.C., Torriani, S.F.F., Croll, D., Stukenbrock, E.H., and McDonald, B.A. (2013) Coevolution and life cycle specialization of plant cell wall degrading enzymes in a hemibiotrophic pathogen. Molecular Biology and Evolution 30: 1337-1347.

Choquer, M., Fournier, E., Kunz, C., Levis, C., Pradier, J.M., Simon, A., and Viaud, M. (2007) Botrytis cinerea virulence factors:new insights into a necrotrophic and polyphageous pathogen. Fems Microbiology Letters 277: 1-10.

Decognet, V., Bardin, M., Trottin-Caudal, Y., and Nicot, P.C. (2009) Rapid change in the genetic diversity of Botrytis cinerea populations after the introduction of strains in a tomato glasshouse. Phytopathology 99: 185-193.

Desprez-Loustau, M.L., Vitasse, Y., Delzon, S., Capdevielle, X., Marcais, B., and Kremer, A. (2010) Are plant pathogen populations adapted for encounter with their host? A case study of phenological synchrony between oak and an obligate fungal parasite along an altitudinal gradient. Journal of Evolutionary Biology 23: 87-97.

Dutech, C., Fabreguettes, O., Capdevielle, X., and Robin, C. (2010) Multiple introductions of divergent genetic lineages in an invasive fungal pathogen, Cryphonectria parasitica, in France. Heredity 105: 220-228.

Dutech, C., Barres, B., Bridier, J., Robin, C., Milgroom, M.G., and Ravigne, V. (2012) The chestnut blight fungus world tour: successive introduction events from diverse origins in an invasive plant fungal pathogen. Molecular Ecology 21: 3931-3946.

Elad, Y., Williamson, B., Tudzynski, P., and Delen, N. (2004) Botrytis spp. and diseases they cause in agricultural systems - an introduction.

Elmer, P.A.G., and Michailides, T.J. (2004) Epidemiology in Botrytis cinerea in orchard and vine crops. In Botrytis: Biology, Pathology and Control. Elad, Y., Williamson, B., Tudzynski, P., and Delen, N. (eds). Dordrecht, The Netherlands: Kluwer Academic Publishers, pp. 243-262.

Evanno, G., Regnaut, S., and Goudet, J. (2005) Detecting the number of clusters of individuals using the software STRUCTURE: a simulation study. Molecular Ecology 14: 2611-2620.

Excoffier, L., and Lischer, H.E.L. (2010) Arlequin suite ver 3.5: a new series of programs to perform population genetics analyses under Linux and Windows. Molecular Ecology Resources 10: $564-567$. 


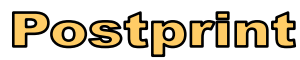

Version définitive du manuscrit publié dans / Final version of the manuscript : Walker, A. S., Gladieux, P., Decognet, V., Fermaud, M., Confais, J., Roudet, J., Bardin, M., Bout, A., Nicot, P. C., Poncet, C., Fournier, E. (2015). Population structure and temporal maintenance of the multihost fungal pathogen Botrytis cinerea: causes and implications for disease management. Environmental Microbiology, 17 (4), 1261-1274, DOI: 10.1111/1462-2920.12563. The original publication is available at http://onlinelibrary.wiley.com/doi/10.1111/1462$2920.12563 /$ abstract

Fournier, E., and Giraud, T. (2008) Sympatric genetic differentiation of a generalist pathogenic fungus, Botrytis cinerea, on two different host plants, grapevine and bramble. Journal of Evolutionary Biology 21: 122-132.

Fournier, E., Giraud, T., Albertini, C., and Brygoo, Y. (2005) Partition of the Botrytis cinerea complex in France using multiple gene genealogies. Mycologia 97: 1251-1267.

Fournier, E., Levis, C., Fortini, D., Leroux, P., Giraud, T., and Brygoo, Y. (2003) Characterization of Bc-hch, the Botrytis cinerea homolog of the Neurospora crassa het-c vegetative incompatibility locus, and its use as a population marker. Mycologia 95: 251-261.

Fournier, E., Giraud, T., Loiseau, A., Vautrin, D., Estoup, A., Solignac, M. et al. (2002) Characterization of nine polymorphic microsatellite loci in the fungus Botrytis cinerea (Ascomycota). Molecular Ecology Notes 2: 253-255.

Frenkel, O., Peever, T.L., Chilvers, M.I., Özkilinc, H., Can, C., Abbo, S. et al. (2010) Ecological genetic divergence of the fungal pathogen Didymella rabiei on sympatric wild and domesticated Cicer spp. (Chickpea). Applied and Environmental Microbiology 76: 30-39.

Giraud, T., Gladieux, P., and Gavrilets, S. (2010) Linking the emergence of fungal plant diseases with ecological speciation. Trends in Ecology \& Evolution 25: 387-395.

Giraud, T., Fortini, D., Levis, C., Leroux, P., and Brygoo, Y. (1997) RFLP markers show genetic recombination in Botryotinia fuckeliana (Botrytis cinerea) and transposable elements reveal two sympatric species. Molecular Biology and Evolution 14: 1177-1185.

Giraud, T., Villareal, L., Austerlitz, F., Le Gac, M., and Lavigne, C. (2006) Importance of the life cycle in sympatric host race formation and speciation of pathogens. Phytopathology 96: 280287.

Gladieux, P., Zhang, X.G., Afoufa-Bastien, D., Sanhueza, R.M.V., Sbaghi, M., and Le Cam, B. (2008) On the origin and spread of the scab disease of apple: out of central Asia. PLoS ONE 3.

Gladieux, P., Vercken, E., Fontaine, M.C., Hood, M.E., Jonot, O., Couloux, A., and Giraud, T. (2011a) Maintenance of fungal pathogen species that are specialized to different hosts: allopatric divergence and introgression through secondary contact. Molecular Biology and Evolution 28: 459-471.

Gladieux, P., Guerin, F., Giraud, T., Caffier, V., Lemaire, C., Parisi, L. et al. (2011b) Emergence of novel fungal pathogens by ecological speciation: importance of the reduced viability of immigrants. Molecular Ecology 20: 4521-4532.

Gladieux, P., Zhang, X.G., Roldan-Ruiz, I., Caffier, V., Leroy, T., Devaux, M. et al. (2010) Evolution of the population structure of Venturia inaequalis, the apple scab fungus, associated with the domestication of its host. Molecular Ecology 19: 658-674.

Gordon, T.R., and Leveau, J.H.J. (2010) Plant Pathology: A Story About Biology. In Annual Review of Phytopathology, Vol 48. VanAlfen, N.K., Bruening, G., and Leach, J.E. (eds), pp. 293309.

Isenegger, D.A., Ades, P.K., Ford, R., and Taylor, P.W.J. (2008) Status of the Botrytis cinerea species complex and microsatellite analysis of transposon types in South Asia and Australia. Fungal Diversity 29: 17-26. 


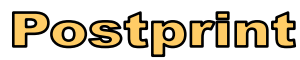

Version définitive du manuscrit publié dans / Final version of the manuscript : Walker, A. S., Gladieux, P., Decognet, V., Fermaud, M., Confais, J., Roudet, J., Bardin, M., Bout, A., Nicot, P. C., Poncet, C., Fournier, E. (2015). Population structure and temporal maintenance of the multihost fungal pathogen Botrytis cinerea: causes and implications for disease management. Environmental Microbiology, 17 (4), 1261-1274, DOI: $10.1111 / 1462-2920.12563$. The original publication is available at http://onlinelibrary.wiley.com/doi/10.1111/14622920.12563/abstract

Jakobsson, M., and Rosenberg, N.A. (2007) CLUMPP: a cluster matching and permutation program for dealing with label switching and multimodality in analysis of population structure. Bioinformatics 23: 1801-1806.

Jaspers, M.V., Seyb, A.M., Trought, M.C.T., and Balasubramaniam, R. (2013) Overwintering grapevine debris as an important source of Botrytis cinerea inoculum. Plant Pathology 62: 130138.

Johnston, P.R., Hoksbergen, K., Park, D., and Beever, R.E. (2013) Genetic diversity of Botrytis in New Zealand vineyards and the significance of its seasonal and regional variation. Plant Pathology: n/a-n/a, DOI: 10.1111/ppa.12143.

Jombart, T. (2008) adegenet: a $\mathrm{R}$ package for the multivariate analysis of genetic markers. Bioinformatics 24: 1403-1405.

Jombart, T., Devillard, S., and Balloux, F. (2010) Discriminant analysis of principal components: a new method for the analysis of genetically structured populations. Bmc Genetics 11.

Karchani-Balma, S., Gautier, A., Raies, A., and Fournier, E. (2008) Geography, plants and growing systems shape the genetic structure of Tunisian Botrytis cinerea populations. Phytopathology 98: 1271-1279.

Leroux, P., Gredt, M., Leroch, M., and Walker, A.-S. (2010) Exploring mechanisms of resistance to respiratory inhibitors in field strains of Botrytis cinerea, the causal agent of gray mold. Applied and Environmental Microbiology 76: 6615-6630.

Ma, Z.H., and Michailides, T.J. (2005) Genetic structure of Botrytis cinerea populations from different host plants in California. Plant Disease 89: 1083-1089.

Martinez, F., Dubos, B., and Fermaud, M. (2005) The role of saprotrophy and virulence in the population dynamics of Botrytis cinerea in vineyards. Phytopathology 95: 692-700.

Martinez, F., Corio-Costet, M.F., Levis, C., Coarer, M., and Fermaud, M. (2008) New PCR primers applied to characterize distribution of Botrytis cinerea populations in French vineyards. Vitis 47: 217-226.

Mboup, M., Bahri, B., Leconte, M., De Vallavieille-Pope, C., Kaltz, O., and Enjalbert, J. (2012) Genetic structure and local adaptation of European wheat yellow rust populations: the role of temperature-specific adaptation. Evolutionary Applications 5: 341-352.

McDonald, B.A., and Linde, C. (2002) The population genetics of plant pathogens and breeding strategies for durable resistance. Euphytica 124: 163-180.

Milgroom, M.G., and Peever, T.L. (2003) Population biology of plant pathogens - The synthesis of plant disease epidemiology and population genetics. Plant Disease 87: 608-617.

Morgan, J.A.T., Vredenburg, V.T., Rachowicz, L.J., Knapp, R.A., Stice, M.J., Tunstall, T. et al. (2007) Population genetics of the frog-killing fungus Batrachochytrium dendrobatidis. Proceedings of the National Academy of Sciences 104: 13845-13850.

Munkacsi, A.B., Stoxen, S., and May, G. (2008) Ustilago maydis populations tracked maize through domestication and cultivation in the Americas. Proceedings of the Royal Society B: Biological Sciences 275: 1037-1046.

Munoz, G., Hinrichsen, P., Brygoo, Y., and Giraud, T. (2002) Genetic characterisation of Botrytis cinerea populations in Chile. Mycological Research 106: 594-601. 


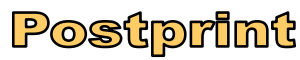

Version définitive du manuscrit publié dans / Final version of the manuscript : Walker, A. S., Gladieux, P., Decognet, V., Fermaud, M., Confais, J., Roudet, J., Bardin, M., Bout, A., Nicot, P. C., Poncet, C., Fournier, E. (2015). Population structure and temporal maintenance of the multihost fungal pathogen Botrytis cinerea: causes and implications for disease management. Environmental Microbiology, 17 (4), 1261-1274, DOI: $10.1111 / 1462-2920.12563$. The original publication is available at http://onlinelibrary.wiley.com/doi/10.1111/14622920.12563/abstract

Peever, T.L., Olsen, L., Ibanez, A., and Timmer, L.W. (2000) Genetic differentiation and host specificity among populations of Alternaria spp. causing brown spot of grapefruit and tangerine x grapefruit hybrids in Florida. Phytopathology 90: 407-414.

Pritchard, J.K., Stephens, M., and Donnelly, P. (2000) Inference of population structure using multilocus genotype data. Genetics 155: 945-959.

Rajaguru, B.A.P., and Shaw, M.W. (2010) Genetic differentiation between hosts and locations in populations of latent Botrytis cinerea in southern England. Plant Pathology 59: 1081-1090.

Raymond, M., and Rousset, F. (1995) GENEPOP (version 1.2): population genetics software for exact tests and ecumenicism. Journal of Heredity 86: 248-249.

Robert, S., Ravigne, V., Zapater, M.F., Abadie, C., and Carlier, J. (2012) Contrasting introduction scenarios among continents in the worldwide invasion of the banana fungal pathogen Mycosphaerella fijiensis. Molecular Ecology 21: 1098-1114.

Roca, M.G., Weichert, M., Siegmund, U., Tudzynski, P., and Fleissner, A. (2012) Germling fusion via conidial anastomosis tubes in the grey mould Botrytis cinerea requires NADPH oxidase activity. Fungal Biology 116: 379-387.

Samuel, S., Veloukas, T., Papavasileiou, A., and Karaoglanidis, G.S. (2012) Differences in frequency of transposable elements presence in Botrytis cinerea populations from several hosts in Greece. Plant Disease 96: 1286-1290.

Simwami, S.P., Khayhan, K., Henk, D.A., Aanensen, D.M., Boekhout, T., Hagen, F. et al. (2011) Low diversity Cryptococcus neoformans variety grubii multilocus sequence types from Thailand are consistent with an ancestral African origin. Plos Pathogens 7.

Stukenbrock, E.H., and McDonald, B.A. (2008) The origins of plant pathogens in agroecosystems. Annual Review of Phytopathology 46: 75-100.

Taylor, J.W., and Fisher, M.C. (2003) Fungal multilocus sequence typing - it's not just for bacteria. Current Opinion in Microbiology 6: 351-356.

Taylor, J.W., Turner, E., Townsend, J.P., Dettman, J.R., and Jacobson, D. (2006) Eukaryotic microbes, species recognition and the geographic limits of species: examples from the kingdom Fungi. Philosophical Transactions of the Royal Society B-Biological Sciences 361: 1947-1963.

The Angiosperm Phylogeny, G. (2009) An update of the Angiosperm Phylogeny Group classification for the orders and families of flowering plants: APG III. Botanical Journal of the Linnean Society 161: 105-121.

Walker, A.-S., Gautier, A., Confais, J., Martinho, D., Viaud, M., Le Pecheur, P. et al. (2011) Botrytis pseudocinerea, a new cryptic species causing gray mold in French vineyards in sympatry with Botrytis cinerea. Phytopathology 101: 1433-1445.

Williams, P.D. (2010) Darwinian interventions: taming pathogens through evolutionary ecology. Trends in Parasitology 26: 83-92.

Williamson, B., Tudzynsk, B., Tudzynski, P., and van Kan, J.A.L. (2007) Botrytis cinerea: the cause of grey mould disease. Molecular Plant Pathology 8: 561-580.

Zhan, J.S., and McDonald, B.A. (2011) Thermal adaptation in the fungal pathogen Mycosphaerella graminicola. Molecular Ecology 20: 1689-1701. 


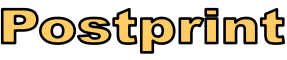

Version définitive du manuscrit publié dans / Final version of the manuscript : Walker, A. S., Gladieux, P., Decognet, V., Fermaud, M., Confais, J., Roudet, J., Bardin, M., Bout, A., Nicot, P. C., Poncet, C., Fournier, E. (2015). Population structure and temporal maintenance of the multihost fungal pathogen Botrytis cinerea: causes and implications for disease management. Environmental Microbiology, 17 (4), 1261-1274, DOI: 10.1111/1462-2920.12563. The original publication is available at http://onlinelibrary.wiley.com/doi/10.1111/1462-2920.12563/abstract

Table 1: Populations of Botrytis cinerea collected in three French regions, on various host plants and in different cropping systems, between 2005 and 2007

\begin{tabular}{|c|c|c|c|c|c|c|c|c|}
\hline \multirow{3}{*}{ Region } & \multirow{3}{*}{ Location } & \multirow{3}{*}{ Host plant ${ }^{\mathrm{a}}$} & \multirow{3}{*}{ Cultivar } & \multicolumn{5}{|c|}{ Sampling date } \\
\hline & & & & September & June & September & June & Total \\
\hline & & & & 2005 & 2006 & 2006 & 2007 & \\
\hline \multirow[t]{9}{*}{ Southwest } & Couhins & Vitis vinifera & Merlot noir & 54 & 24 & 63 & 59 & 200 \\
\hline & Fauguerolles & $\begin{array}{l}\text { Solanum } \\
\text { lycopersicum }\end{array}$ & Palmiro & 26 & 16 & 32 & 28 & 102 \\
\hline & Fauillet & $\begin{array}{l}\text { Solanum } \\
\text { lycopersicum }\end{array}$ & Hipop & 32 & 18 & 24 & - & 74 \\
\hline & Grande-Ferrade & Rubus fruticosus & Wild & 26 & 33 & 25 & 27 & 111 \\
\hline & & Vitis vinifera & Merlot noir & 50 & 41 & 65 & 55 & 211 \\
\hline & & Litter & - & 30 & 42 & 73 & 46 & 191 \\
\hline & Saint Julien & Rubus fruticosus & Wild & 28 & 31 & 28 & 27 & 114 \\
\hline & & Vitis vinifera & Merlot noir & 55 & 44 & 56 & 57 & 212 \\
\hline & Marmande & $\begin{array}{l}\text { Solanum } \\
\text { lycopersicum }\end{array}$ & Palmiro & - & 19 & 11 & 30 & 60 \\
\hline \multirow[t]{10}{*}{ Northeast } & Courceroy & $\begin{array}{l}\text { Solanum } \\
\text { lycopersicum }\end{array}$ & Moneymaker & - & 6 & 55 & 48 & 109 \\
\hline & Courteron & Rubus fruticosus & Wild & 18 & 4 & 46 & 25 & 93 \\
\hline & & Vitis vinifera & Pinot meunier & 53 & 50 & 99 & 30 & 232 \\
\hline & & Litter & - & 19 & 1 & - & - & 20 \\
\hline & Foissy-sur- & Solanum & Moneymaker & 24 & 50 & - & - & 74 \\
\hline & Vanne & lycopersicum & & - & - & 22 & 10 & 32 \\
\hline & & Rubus fruticosus & Wild & & & & & \\
\hline & Hautvillers & Vitis vinifera & Pinot noir & 93 & 59 & 108 & 47 & 307 \\
\hline & Vandières & Rubus fruticosus & Wild & 23 & 18 & 17 & 28 & 86 \\
\hline & & Vitis vinifera & Pinot noir & 63 & 84 & 85 & 29 & 261 \\
\hline \multirow[t]{2}{*}{ Southeast } & Carnoules & Vitis vinifera & Syrah & 8 & - & - & - & 8 \\
\hline & La Farlède & Vitis vinifera & Rolle & 20 & 7 & 14 & 7 & 48 \\
\hline
\end{tabular}




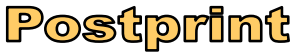

Version définitive du manuscrit publié dans / Final version of the manuscript : Walker, A. S., Gladieux, P., Decognet, V., Fermaud, M., Confais, J., Roudet, J., Bardin, M., Bout, A., Nicot, P. C., Poncet, C., Fournier, E. (2015). Population structure and temporal maintenance of the multihost fungal pathogen Botrytis cinerea: causes and implications for disease management. Environmental Microbiology, 17 (4), 1261-1274, DOI: 10.1111/1462-2920.12563. The original publication is available at http://onlinelibrary.wiley.com/doi/10.1111/1462-2920.12563/abstract

\begin{tabular}{|c|c|c|c|c|c|c|c|c|}
\hline & & Litter & - & 22 & 32 & - & 1 & 55 \\
\hline & Lançon- & Rubus fruticosus & Wild & 16 & - & 31 & 18 & 65 \\
\hline & Provence & Vitis vinifera & Grenache & 30 & 29 & 30 & 30 & 119 \\
\hline & & Litter & - & 30 & 13 & 24 & 30 & 97 \\
\hline & & $\begin{array}{l}\text { Solanum } \\
\text { lycopersicum }\end{array}$ & Alison & 30 & 30 & 30 & 30 & 120 \\
\hline & Pierrelatte & $\begin{array}{l}\text { Solanum } \\
\text { lycopersicum }\end{array}$ & Hipop & 30 & 30 & 30 & 30 & 120 \\
\hline & Sarrians & Rubus fruticosus & Wild & 31 & - & 30 & 31 & 92 \\
\hline & & Vitis vinifera & Grenache & 30 & 25 & 30 & 29 & 114 \\
\hline & & Litter & - & 39 & - & 30 & 30 & 99 \\
\hline & & $\begin{array}{l}\text { Solanum } \\
\text { lycopersicum }\end{array}$ & Emotion/Alison & 30 & 30 & 30 & 30 & 120 \\
\hline Total & & & & 910 & 736 & 1088 & 812 & 3546 \\
\hline
\end{tabular}

${ }^{a}$ On grapevine (Vitis vinifera) and bramble (Rubus fruticosus), samples were collected from diseased berries in the fall, and from flower caps or decaying flower parts in spring. Vitis samples were collected from open-field cultivated plots. Rubus samples were collected from plants surrounding the grapevine plots. On litter, samples were collected from asymptomatic wild- or crop-plant debris on the ground within or very close to grapevine plots in all seasons. On tomato (Solanum lycopsersicum), samples were collected from diseased fruits in all seasons, either in high-tech (Lançon-Provence, Courceroy, Pierrelatte, Sarrians) or low-tech (Fauguerolles, Fauillet, Foissy sur Vanne, Marmande) greenhouses.

- Indicates missing data, i.e. populations not collected because the disease was inexistent at this date or because samples never recovered living colonies. 


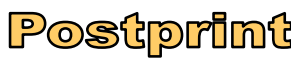

Version définitive du manuscrit publié dans / Final version of the manuscript : Walker, A. S., Gladieux, P., Decognet, V., Fermaud, M., Confais, J., Roudet, J., Bardin, M., Bout, A., Nicot, P. C., Poncet, C., Fournier, E. (2015). Population structure and temporal maintenance of the multihost fungal pathogen Botrytis cinerea: causes and implications for disease management. Environmental Microbiology, 17 (4), 1261-1274, DOI: 10.1111/1462-2920.12563. The original publication is available at http://onlinelibrary.wiley.com/doi/10.1111/1462-2920.12563/abstract

Table 2: Hierarchical analyses of molecular variance (AMOVA) with (i) sampling dates as grouping factor (upper table), and (ii) geographic origin and host of origin nested within geographic origin as grouping factors (lower table).

\begin{tabular}{lllllll}
\hline & d.f. & $\begin{array}{l}\text { Sum of } \\
\text { squares }\end{array}$ & $\begin{array}{l}\text { Variance } \\
\text { components }\end{array}$ & $\begin{array}{l}\text { Percentage } \\
\text { of variation }\end{array}$ & $P$-value & $\begin{array}{l}\text { Fixation } \\
\text { indices }\end{array}$ \\
\hline Among dates & 1 & 90 & 0.03 & 1.09 & $<\mathbf{0 0 1}$ & 0.01 \\
Within dates & 3542 & 9915 & 2.80 & 98.91 & & \\
Total & 3545 & 10005 & 2.83 & & & \\
\hline
\end{tabular}

\begin{tabular}{|c|c|c|c|c|c|c|}
\hline & d.f. & $\begin{array}{l}\text { Sum of } \\
\text { squares }\end{array}$ & $\begin{array}{l}\text { Variance } \\
\text { components }\end{array}$ & $\begin{array}{l}\text { Percentage } \\
\text { of variation }\end{array}$ & $\mathrm{P}$-value & $\begin{array}{l}\text { Fixation } \\
\text { indices }\end{array}$ \\
\hline \multicolumn{7}{|l|}{ September 2005} \\
\hline Among regions & 2 & 101 & -0.16 & -6.05 & 0.738 & -0.06 \\
\hline Among hosts within regions & 8 & 439 & 0.81 & 29.67 & $<0.001$ & 0.28 \\
\hline Within hosts & 869 & 1810 & 2.08 & 76.38 & $<0.001$ & 0.24 \\
\hline Total & 879 & 2350 & 2.73 & & & \\
\hline \multicolumn{7}{|l|}{ June 2006} \\
\hline Among regions & 2 & 130 & -0.16 & -5.36 & 0.728 & -0.05 \\
\hline Among hosts within regions & 8 & 476 & 1.05 & 34.85 & $<0.001$ & 0.33 \\
\hline Within hosts & 725 & 1534 & 2.12 & 70.51 & $<0.001$ & 0.29 \\
\hline Total & 735 & 2140 & 3.01 & & & \\
\hline \multicolumn{7}{|l|}{ September 2006} \\
\hline Among regions & 2 & 97 & -0.17 & -6.17 & 0.782 & -0.06 \\
\hline Among hosts within regions & 8 & 555 & 0.80 & 29.08 & $<0.001$ & 0.27 \\
\hline Within hosts & 1077 & 2288 & 2.12 & 77.09 & $<0.001$ & 0.23 \\
\hline Total & 1087 & 2940 & 2.75 & & & \\
\hline \multicolumn{7}{|l|}{ June 2007} \\
\hline Among regions & 2 & 57 & -0.13 & -4.40 & 0.845 & -0.44 \\
\hline Among hosts within regions & 8 & 405 & 0.70 & 23.44 & $<0.001$ & 0.23 \\
\hline Within hosts & 801 & 1950 & 2.43 & 80.95 & $<0.001$ & 0.19 \\
\hline Total & 811 & 2412 & 3.00 & & & \\
\hline
\end{tabular}

$P$-values in bold are significant at the $5 \%$ confidence level 


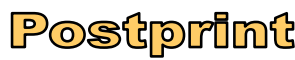

Version définitive du manuscrit publié dans / Final version of the manuscript : Walker, A. S., Gladieux, P., Decognet, V., Fermaud, M., Confais, J., Roudet, J., Bardin, M., Bout, A., Nicot, P. C., Poncet, C., Fournier, E. (2015). Population structure and temporal maintenance of the multihost fungal pathogen Botrytis cinerea: causes and implications for disease management. Environmental Microbiology, 17 (4), 1261-1274, DOI: 10.1111/1462-2920.12563. The original publication is available at http://onlinelibrary.wiley.com/doi/10.1111/1462-2920.12563/abstract

Table 3. Assignment of genotypes collected at a given sampling date $(t)$ to the 5 genetic clusters inferred at the previous sampling date $(t-1)$.

\begin{tabular}{|c|c|c|c|c|}
\hline Clusters from date $t-1$ & \multicolumn{4}{|c|}{$\begin{array}{l}\text { Proportion of genotypes from date } t \text { assigned to the } \\
\text { clusters identified at date } t-1\end{array}$} \\
\hline June 2006 & $\begin{array}{l}\text { Solanum } \\
(\mathrm{n}=199)\end{array}$ & $\begin{array}{l}\text { Rubus } \\
(\mathrm{n}=86)\end{array}$ & $\begin{array}{l}\text { Vitis } \\
(\mathrm{n}=363)\end{array}$ & $\begin{array}{l}\text { Litter } \\
(\mathrm{n}=88)\end{array}$ \\
\hline SOLANUM & 0.859 & 0 & 0.011 & 0 \\
\hline RUBUS & 0 & 0.756 & 0.143 & 0.216 \\
\hline VITIS & 0.005 & 0.093 & 0.253 & 0.216 \\
\hline Not assigned & 0.136 & 0.151 & 0.592 & 0.568 \\
\hline September 2006 & $\begin{array}{l}\text { Solanum } \\
(\mathrm{n}=212)\end{array}$ & $\begin{array}{l}\text { Rubus } \\
(\mathrm{n}=199)\end{array}$ & $\begin{array}{l}\text { Vitis } \\
(\mathrm{n}=550)\end{array}$ & $\begin{array}{l}\text { Litter } \\
(\mathrm{n}=127)\end{array}$ \\
\hline SOLANUM & 0.821 & 0.020 & 0 & 0 \\
\hline RUBUS & 0 & 0.090 & 0 & 0 \\
\hline VITIS & 0.052 & 0.568 & 0.455 & 0.630 \\
\hline Not assigned & 0.127 & 0.322 & 0.545 & 0.370 \\
\hline September 2006 & $\begin{array}{l}\begin{array}{l}\text { Solanum } \\
(\mathrm{n}=196)\end{array} \\
\end{array}$ & $\begin{array}{l}\text { Rubus } \\
(\mathrm{n}=166)\end{array}$ & $\begin{array}{l}\text { Vitis } \\
(\mathrm{n}=343)\end{array}$ & $\begin{array}{l}\text { Litter } \\
(\mathrm{n}=107)\end{array}$ \\
\hline SOLANUM & 0.668 & 0 & 0.006 & 0 \\
\hline RUBUS & 0.087 & 0.404 & 0.087 & 0.121 \\
\hline VITIS & 0.031 & 0.229 & 0.489 & 0.411 \\
\hline Not assigned & 0.214 & 0.367 & 0.420 & 0.467 \\
\hline
\end{tabular}

Analyses were carried out using USEPOPINFO option of the STRUCTURE program. To increase the stringency of the analysis, the 5 genetic clusters of date $t-l$ were defined on the basis of genotypes that had membership coefficients greater than 0.9 in any of these clusters. Genotypes from date $t$ were considered 'assigned' to a given cluster from data $t-1$ if their membership coefficient in this cluster was above 0.70 . 


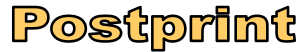

Version définitive du manuscrit publié dans / Final version of the manuscript : Walker, A. S., Gladieux, P., Decognet, V., Fermaud, M., Confais, J., Roudet, J., Bardin, M., Bout, A., Nicot, P. C., Poncet, C., Fournier, E. (2015). Population structure and temporal maintenance of the multihost fungal pathogen Botrytis cinerea: causes and implications for disease management. Environmental Microbiology, 17 (4), 1261-1274, DOI: 10.1111/1462-2920.12563. The original publication is available at http://onlinelibrary.wiley.com/doi/10.1111/14622920.12563/abstract

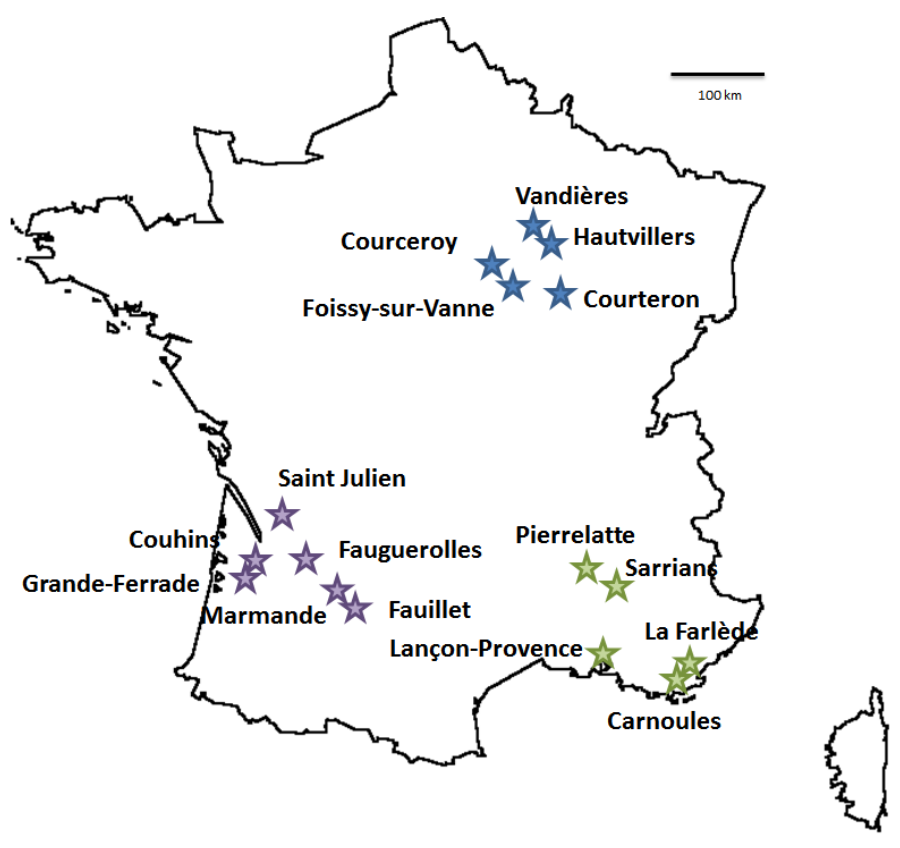

Figure 1: Map of Botrytis cinerea populations collected from three French regions on various host plants and in various cropping conditions, on four dates between 2005 and 2007. Locations from the Northeast,Southwest and Southeast of France are shown in blue, purple, and green, respectively. 
Version définitive du manuscrit publié dans / Final version of the manuscript : Walker, A. S., Gladieux, P., Decognet, V., Fermaud, M., Confais, J., Roudet, J., Bardin, M., Bout, A., Nicot, P. C., Poncet, C., Fournier, E. (2015). Population structure and temporal maintenance of the multihost fungal pathogen Botrytis cinerea: causes and implications for disease management. Environmental Microbiology, 17 (4), 1261-1274, DOI: 10.1111/1462-2920.12563. The original publication is available at http://onlinelibrary.wiley.com/doi/10.1111/14622920.12563/abstract

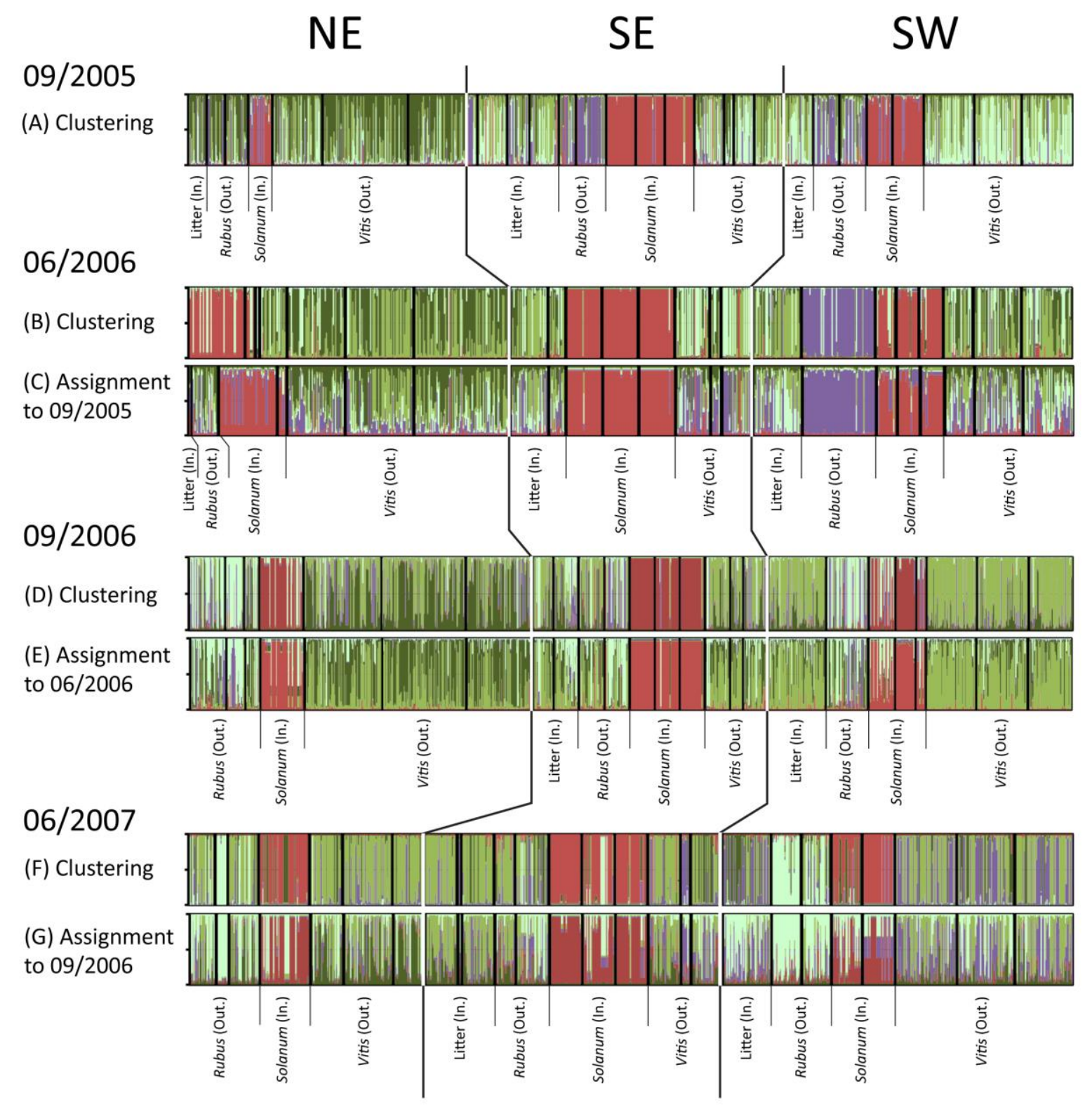

Figure 2: Barplots of the STRUCTURE analysis showing genetic subdivision of the $3546 B$. cinerea isolates collected between 2005 and 2007 into five genetic clusters and the temporal maintenance of this subdivision.

The origin of isolates (host plant and geography) is indicated below each horizontal axis and on the top of the figure. The colours represent cluster membership of the individuals: red: SOLANUM clusters, purple: RUBUS clusters, green: VITIS clusters (VITIS1: dark green, VITIS2: medium green, VITIS3: light green).The cropping system is referred as "In" (indoor) or "Out" (outdoor). Plots A, $\mathrm{B}, \mathrm{D}$ and $\mathrm{F}$ result from the assignment of the isolates collected at season $t$ into the five genetic clusters. Plots C, E and G were built to assess whether the genetic subdivision assessed at one date was maintained at the following date. These plots represent how genotypes collected at season $t+1$ are assigned into genetic clusters inferred at season $t$ (these last being used as learning samples by STRUCTURE, and being defined using genotypes collected at season $t-1$ and having a membership coefficient over or equal to 0.9 into a single cluster at this date). 


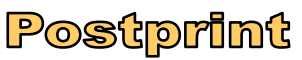

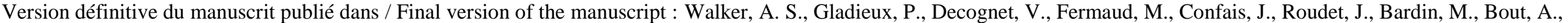

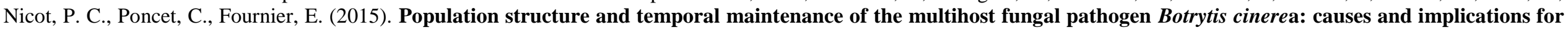

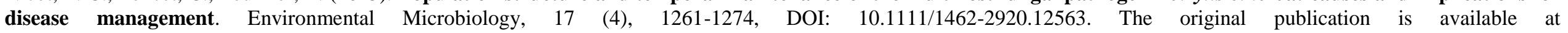
http://onlinelibrary.wiley.com/doi/10.1111/1462-2920.12563/abstract
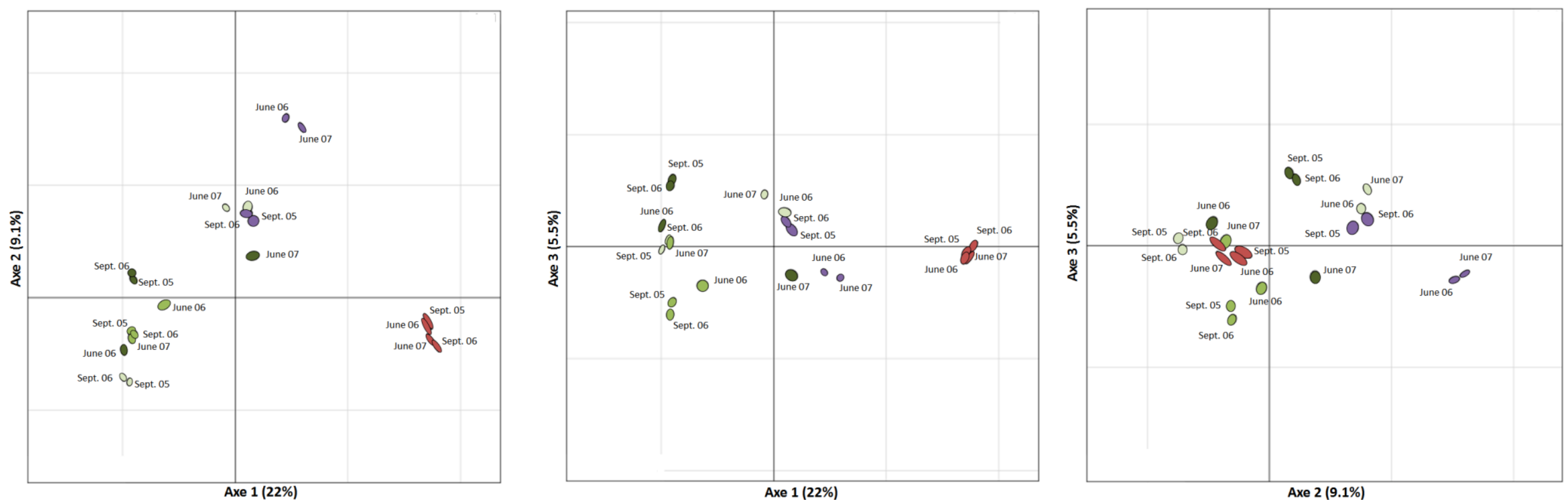

Figure 3: Principal components analysis (PCA) of the 3546 B. cinerea isolates collected between 2005 and 2007 on several hosts.

Individuals were organized into 20 groups (5 genetic clusters of origin x 4 sampling dates). The colours represent cluster membership of the individuals: red: SOLANUM clusters, purple: RUBUS clusters, green: VITIS clusters (VITIS1: dark green, VITIS2: medium green, VITIS3: light green). Only centers of inertia ellipses are represented 


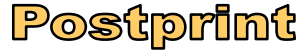

Version définitive du manuscrit publié dans / Final version of the manuscript : Walker, A. S., Gladieux, P., Decognet, V., Fermaud, M., Confais, J., Roudet, J., Bardin, M., Bout, A., Nicot, P. C., Poncet, C., Fournier, E. (2015). Population structure and temporal maintenance of the multihost fungal pathogen Botrytis cinerea: causes and implications for disease management. Environmental Microbiology, 17 (4), 1261-1274, DOI: 10.1111/1462-2920.12563. The original publication is available at http://onlinelibrary.wiley.com/doi/10.1111/14622920.12563/abstract

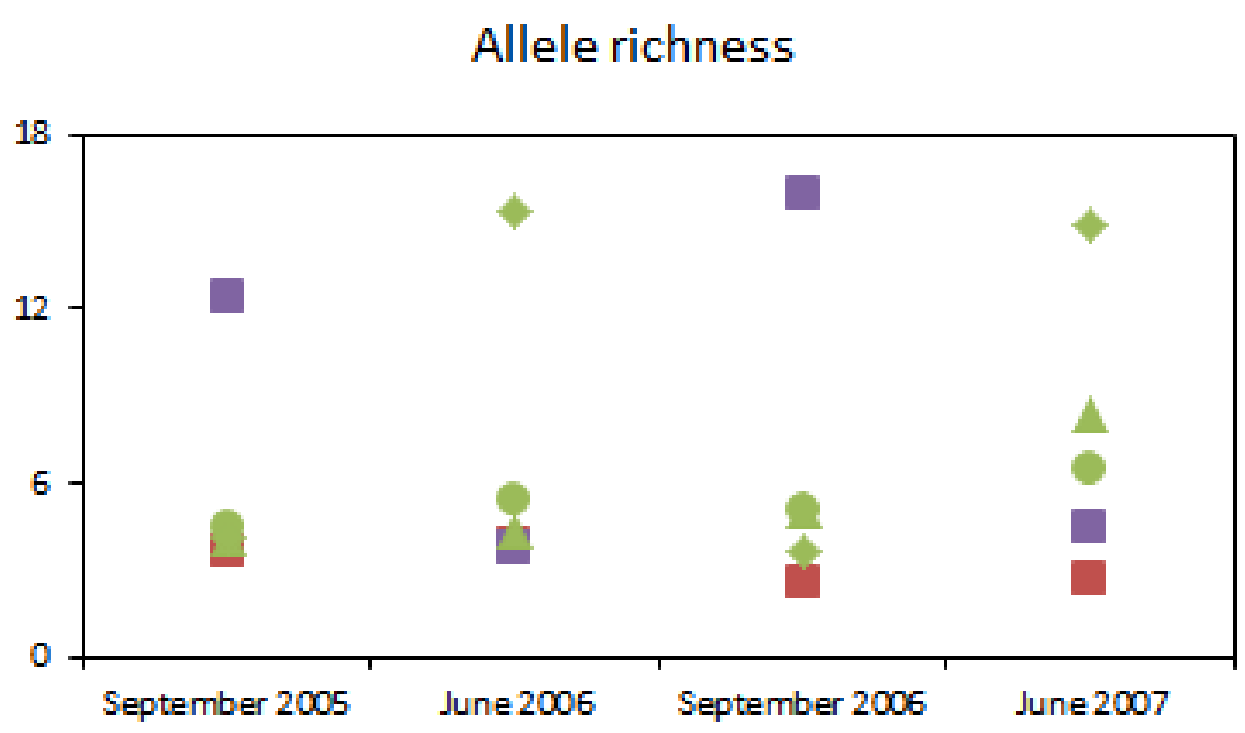

\section{Genic diversity}

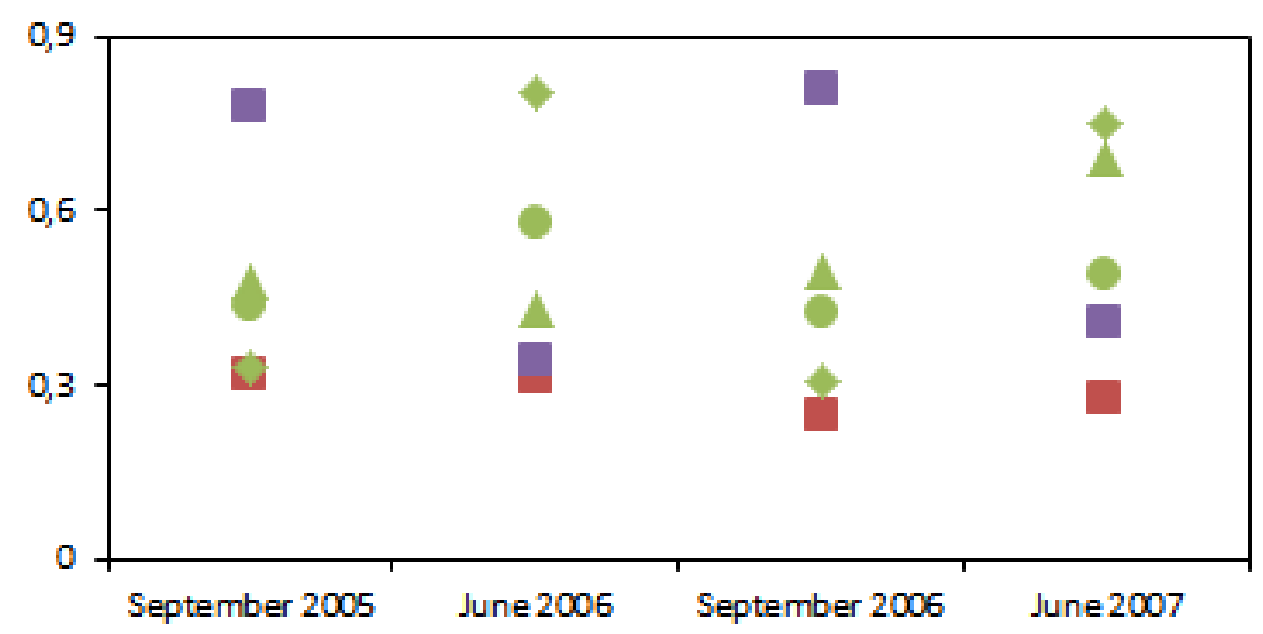

Figure 4: Diversity measured in the five $B$. cinerea clusters and for the four sampling dates.

Colors and marks indicate clusters: INDOOR (red), RUBUS (purple), VITIS1 (green, triangles), VITIS2 (green, circles) and VITIS3 (green, diamonds). Allele richness is calculated as the mean number of alleles per locus. Genic diversity is measured as the mean expected heterozygosity $\left(H_{e}\right)$ over the eight loci. All the values were significant at the $5 \%$ confidence level. 


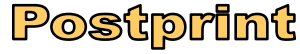

Version définitive du manuscrit publié dans / Final version of the manuscript : Walker, A. S., Gladieux, P., Decognet, V., Fermaud, M., Confais, J., Roudet, J., Bardin, M., Bout, A., Nicot, P. C., Poncet, C., Fournier, E. (2015). Population structure and temporal maintenance of the multihost fungal pathogen Botrytis cinerea: causes and implications for disease management. Environmental Microbiology, 17 (4), 1261-1274, DOI: 10.1111/1462-2920.12563. The original publication is available at http://onlinelibrary.wiley.com/doi/10.1111/1462$2920.12563 /$ abstract

\section{Clonal fraction}

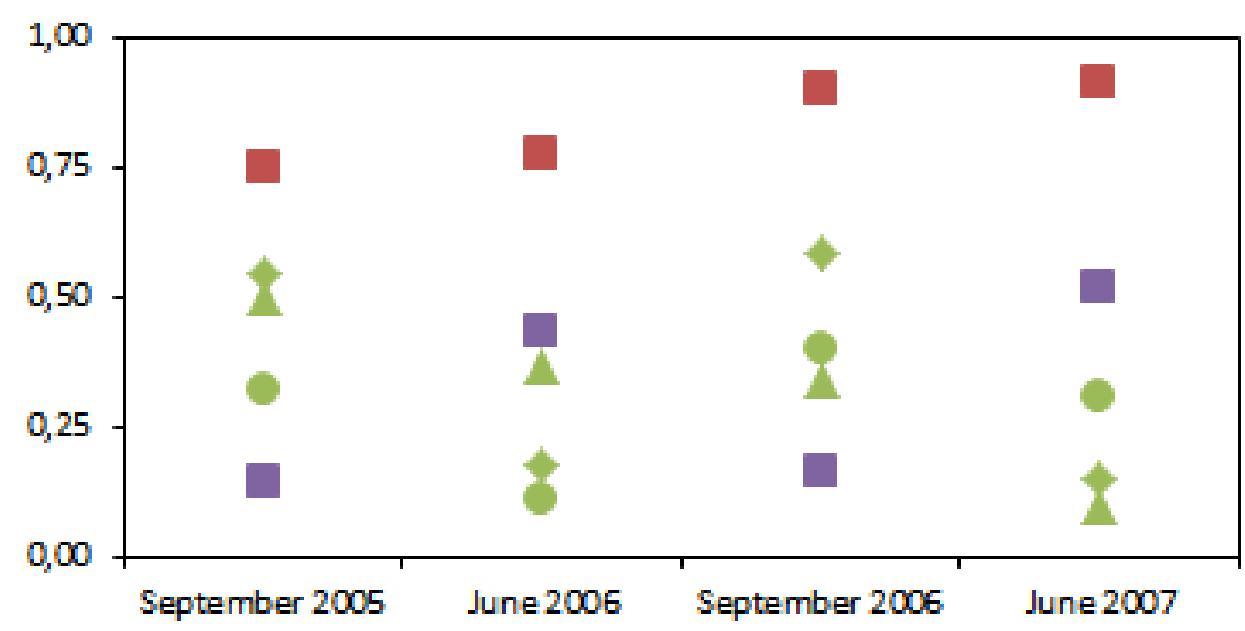

Multilocus linkage disequilibrium

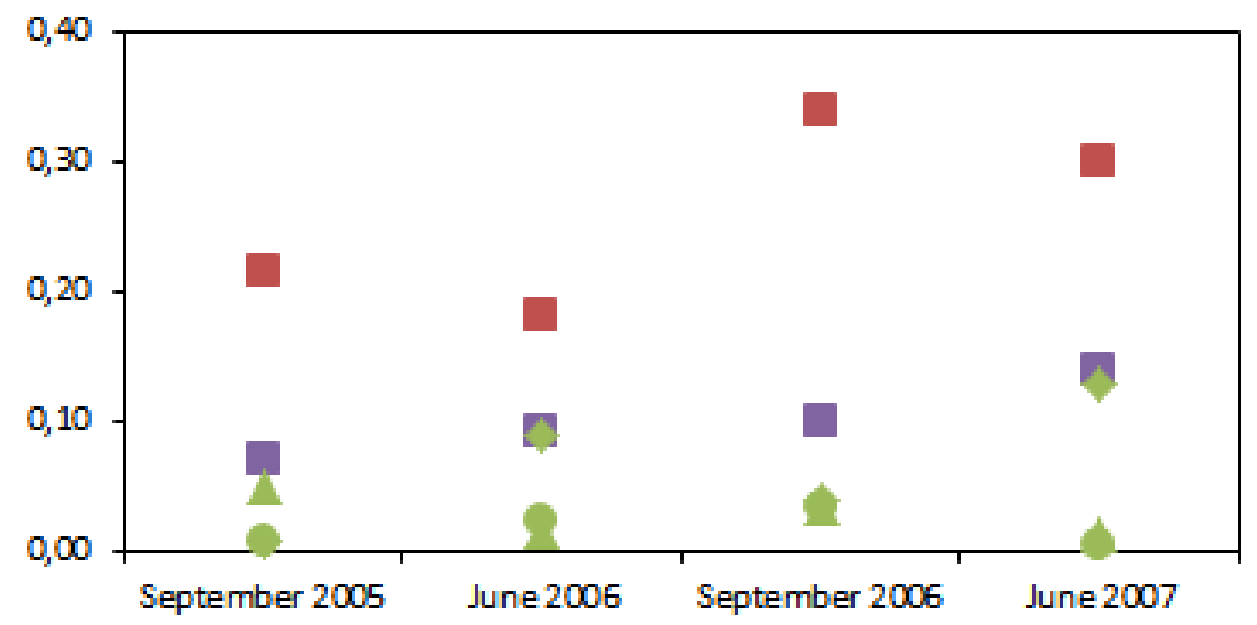

Figure 5: Clonal fraction, multilocus linkage disequilibrium, and numbers of significantly linked pairs of loci in the five clusters identified by clustering analyses. Clusters: INDOOR (red square), RUBUS (purple square), VITIS1 (green triangles), VITIS2 (green circles) and VITIS3 (green diamonds). The clonal fraction represents the proportion of different multilocus genotypes. Multilocus linkage disequilibrium was estimated with the $r_{D}$ index. 